THLRSIAY, FEBRLARY 19, 1920.

\section{THE ORGANISATION OF SCIENTIFIC} WORK IN INIDIA.

$\mathrm{T}$ HE reorganisation and development of scientific work in India are now under consideration, and important and far-reaching decisions on these questions will shortly be made by the Secretary of State. It has already been decided, both by the Government of India and by the Secretary of State, that large sums of money must be found at the carliest possible moment for the purpose of fosteriner the development of the Indian Empire by means of scientific research. The principle of State aid on a generous scale has been accepted, but the important question of the best method of utilising this form of assistance in the future development of India remains to be settled. These matters were referred to by the Viceroy on January 30 last in his speech opening the present session of the Imperial Legislative Council at Delhi. It is evident from the report of Lord Chelmsford's remarks which appeared in the Times of February 6 that the Government of India is now considering large schemes of expansion in regard to the scientific activities of the State.

Two policies at present hold the field: (a) Centralisation under a proposed Imperial Department of Industries of the Government of India in which chemists, botanists, zoologists, and so on will be formed into distinct, water-tight, graded services, each under the control of a departmental head; and $(b)$ decentralisation under which the scientific workers at the various universities and research institutes will be given as free a hand as possible.

The policy of centralisation and the creation of graded scientific services have been strongly advocated by the Indian Industrial Commission, which was presided over by Sir Thomas Holland, formerly I) irector of the (reological Survey of India. It is faroured by a number of administrators in India who consider that some measure of official control is necessary for all scientific investigators, and it has also received the support of several of the scientific witnesses examined by the Commission. The arguments advanced by Sir Thomas Holland and his supporters in favour of centralised scientific services are set out in detail in chap. ix. of the Report of the Indian Industrial Commission, published last year (H.M. Stationery Office; Cmd. 51). The nature of these arguments No. 2625 , VOL. IO4] will be evident from a study of the principles and the rules which they suggest should be adopted for the formation and control of the new Chemical Service. It is proposed to proceed with the creation of this service as soon as the committee now dealing with this matter in India has submitted its report.

The Industrial Commission considers that for administrative purposes the chemists now employed by the State in India, and at present distributed among the cadres of various services, should be brought together into one service to be called the Indian Chemical Service, and should be under the control, so far as their scientific work is concerned, of a senior officer styled Chief Chemist to the Government of India. The remaining members of the service would be divided into three groups---agricultural, mineral, and organic chemists-each group being under the supervision of a Deputy Chief Chemist located at a suitable centre. The junior members of the groups would be lent to Local Governments and to various Government Departments for periods normally limited to five years; they would carry out the routine duties required, in some cases including teaching, and undertake certain forms of research with the approval of the head of the service. All the members of the Chemical Service would carry on their duties on the following lines: (i) Whenever it is possible to lay down for any officer a programme of research work, such programme would not be sanctioned without the consent of the head of the service; (ii) the head of the Chemical Service would have power to inspect the scientific work of any of his transferred officers and to report thereon to the local authority; (iii) the results of scientific investigations would be reviewed by the head of the service, and would not be published without his consent. Ordinarily, such results would be given their first formal publication in the official journal of the service.

These details will enable men of science in Great Britain to understand how it is proposed that most of the future scientific work in India should be conducted. As soon as the organisation of chemists is completed, the Industrial Commission suggests that the botanists, zoologists, and entomologists working in India should be formed into similar centralised services.

The present system under which research is conducted in India may be described shortly as one of decentralisation, the work being carried out at the various university colleges and at a number of independent research institutes under 
the control of the Government of India, the Local Governments, the Indian States, and trusts, of which latter the Indian Institute of Science at Bangalore is the chief example. A large number of the most successiul investigators working in the universities and at the various research institutes do not favour centralisation in separate scientific scrvices, but consider that the present sistem should be developed and extended, and that in applied science the bond of union of the workers engaged should be the general subject investigated, such as agriculture or forestry, rather than the particular science involved. At present the investigators dealing with a manysided subject like agriculture are collected at agricultural research institutes, and now belong to the agricultural department. $\Lambda$ similar method of organisation obtains in forestry and at the centres of medical research like Calcutta and Bombay.

The present system has proved successful in practice, atid the value of the work done in India in pure science, in tropical diseases, in agriculture, and in forestry has been widely recognised. Decentralisation, therefore, has becn justified by success, and a very strong case will have to be made out before the workers at the existing institutes are re-grouped in centralised services under the control, as regards their scientific work, of the proposed Department of Industries of the (iovernment of India.

Increased financial assistance on the part of the State would enable the present universitics and research institutes to be developed and more workers secured. With such facilities, there should be the greatest possible frecdom for the investignators carrving on original work. The grencral conditions under which the researches are conducted should be made as attractive as possible, and the policy to be adopted should be one which would secure the very best men available, and the provision of adequate means for their work. For original scientific investigators little or no official control is needed, and they should not be constantly called upon to furnish interim reports and programmes of work to an official chief, or to obtain his formal sanction before undertaking an investigation or publishing the results of their work. Such formalities waste valuatble time, lead to constant friction, and are altogether foreign to the spirit which should reign in all centres of creative scientific research.

Brictly stated, the case to be decided is on: between the adrocaltes of a system of rigid centralisation and those who consider that in research vo. 2625, VOL. IO4] work the man is everything, and that there can be no progress without freedom. Obviously, the conflict of opinion is a fundamental one, and much will depend on the wisdom and sympathies of the Secretary of State, with whom the final word lies, in decidingr which policy is to prevail.

\section{MOIDIRII PHISIOLOGI.}

An Introduction to (ieneral Physiology: With Practical Fxercises. By Prof. WV. M. Bayliss. Pp. $x v+238$. (London: Longmans, (ireen, and Co., 1919.) P'rice $7 s .6 d$. net.

" THE task of physiologists is to refer, as far $I$ as they can, all phenomena of life to the laws of physics and chemistry." With this definition Prof. Bayliss presents the student with those fundamental principles of these sciences which are of primary importance in the study of physiolog!. It is quite remarkable. how the author can compress these principles into a small compass, and at the same time give such a clear picture, not only of these parts of physics and chemistry, but alse of their applications in phrsiology. It is essentially an introduction to the author's "Principles of General Physiology," and reference is constantly made to this larger book. The student would often welcome, at these places, it rather longer description, for he will probably not possess the larecer book at this period of his scienre course.

The birk is so full of interest that if it wore at little longer the beginner would not be overwhelmed, but would gather all the more fruit. The: first chapter, contitled "Life and Energe", contains those parts of phesics concerned in vital phenonena, written in illustration of certain phenomena easily observed with an anox-ba. Brounian movement is the risualisation of the moving molcules in a liquid. Protoplasm is a liquid containinger matter both in solution and in suspension, and is surrounded by a cell membrane. Surface properties are those mainly concerned, but no grasp of their complexity is possible without a knowledge of energy and its laws. 1 consicierible section is devoted to this subject. The changere of energy at the surface of the cell in the catuse of extrusion of the pscudopodium. The entry into and exit of matter from the coll is connected with osmosis and the permeatbility of membranes. This is most lucidly explained. Flectrolytic dissociation and the colloidal state are included in the chapter.

"Food Digestion and Respiration" are deall with in the second (hapter. A short cut is made. through organic (hemistry so as to give a ron- 